\title{
A comparison of in vitro bioassays to determine cellular glucocorticoid sensitivity
}

\author{
H Vermeer, B I Hendriks-Stegeman, A A Verrijn Stuart, S C van Buul-Offers and M Jansen \\ Department of Pediatric Endocrinology, HP KC.03.063.0, Wilhelmina Children's Hospital, University Medical Center Utrecht, PO Box 85090, \\ 3508 AB, Utrecht, The Netherlands
}

(Correspondence should be addressed to M Jansen; Email: M.Jansen@wkz.azu.nl)

\begin{abstract}
An altered cellular glucocorticoid (GC) sensitivity is associated with several pathophysiological conditions such as asthma, diabetes, or rheumatoid arthritis. Several bioassays have been developed and employed to assess cellular GC sensitivity of peripheral blood mononuclear cells (PBMC), but correlations between these have rarely been investigated. We have compared four mitogen-based assays and an FK506 binding protein 51 (FKBP51) mRNA induction assay, using ten controls and a GCresistant patient. The mitogen-based assays were performed using either diluted wholeblood or isolated PBMC, and showed relatively large assay variations for the parameters maximal effect and half-maximal effect concentration. The FKBP51 assay showed smaller intra-assay and within-individual variation compared with the mitogen-based assays. The wholeblood-based mitogen assays and the FKBP51 assay clearly discriminated the GC-resistant patient from the controls but, in contrast to expectations, both PBMC-based mitogen assays did not. The GC-induced FKBP51 mRNA increase in PBMC may be an alternative to determine an altered individual GC sensitivity with several advantages as compared with mitogen-based assays, such as the use of unstimulated PBMC, and a better intra- and inter-individual reproducibility.
\end{abstract}

European Journal of Endocrinology 150 41-47

\section{Introduction}

Glucocorticoids (GCs) are commonly prescribed to combat diseases with a chronic inflammatory component, such as inflammatory bowel disease, autoimmune diseases, and asthma. Apart from their desired therapeutic effects, GCs influence virtually every tissue, altering gene transcription and protein expression, which may result in undesirable sideeffects such as suppression of the hypothalamic-pituitary-adrenal axis, hypertension, or osteopenia (1-3). Decreased systemic GC activity has been realized by the introduction of GCs with enhanced topical potency and increased metabolism during the hepatic first pass. These GCs are used in the treatment of, among others, skin diseases and asthma $(4,5)$. However, some patients appear hypersensitive to GCs, as they develop side-effects even on low doses of topically applied GCs (6), while other patients appear to be resistant to GCs, as they show no clinical response to treatment $(7,8)$. It is therefore important to be able to identify GC hypo- or hypersensitivity, in order to provide treatment tailored to the needs of the individual patient.
The clinical response to GC treatment is dependent on both the bioavailability of GCs and the intrinsic, cellular sensitivity to GCs. For the determination of GC bioavailability in human serum, several bioassays have been developed, based on activation of a transfected GC-responsive reporter gene $(9,10)$.

To determine cellular GC sensitivity, on the other hand, the most frequently used assays are based on the ability of GCs to inhibit the mitogen-induced proliferation of peripheral blood mononuclear cells (PBMC). Numerous protocols have been described, differing in, for example, the use of diluted wholeblood or isolated PBMC, the type and concentration of mitogen, and the incubation time (11-15). Such differences, however, may affect the results obtained with these bioassays $(16,17)$. Moreover, the GC sensitivity of stimulated PBMC may very well be affected by the stimulation itself, as transcription and translation patterns are profoundly altered by mitogens $(18-20)$. To avoid such 'induced' alterations of GC sensitivity, we developed a bioassay to assess cellular GC sensitivity using native, unstimulated PBMC. This bioassay is based on the GC-induced increase of FK506 binding protein 51 (FKBP51) (21) mRNA, detected using realtime PCR to minimize the number of PBMC required. 
We have previously shown that this bioassay is specific, reproducible, and able to identify certain forms of GC resistance (22).

In this report we have compared four different protocols of mitogen-based GC sensitivity assays, and the FKBP51-based bioassay. Mitogen-based GC sensitivity assays result in sigmoid-shaped, decreasing dose-response curves which can be compared with each other using the parameters maximal effect $\left(\mathrm{E}_{\max }\right)$ and half-maximal effect concentration $\left(\mathrm{EC}_{50}\right)$. Since the increase of FKBP 51 mRNA on average does not reach maximal levels at the concentrations of dexamethasone (DXM) tested, the parameters $\mathrm{E}_{\max }$, and thus $\mathrm{EC}_{50}$, could not be calculated for the FKBP51 assay. We have therefore compared the $\mathrm{E}_{\max }$ of the mitogen assays to relative FKBP51 mRNA levels following incubation with $10^{-6} \mathrm{M}$ DXM. We have determined coefficients of variation $(\mathrm{CV})$ and the reliability with which the different assays distinguish a well-characterized, partially GC-resistant patient $(14,23)$ from normal controls.

\section{Materials and methods}

\section{Preparation of samples}

Ten control patients without a history of GC medication (five males, five females; mean age 37 years; range 22-54 years), and a partially GC-resistant patient (female; age 36 years) were included in this study. This patient was previously shown to have one nonfunctional GC receptor allele, resulting in a functional GC receptor expression of approximately 50\% (14, 23). The patient was prescribed $0.5 \mathrm{mg} \mathrm{DXM} /$ day at the time of venipuncture. Blood was collected in sodium heparin tubes by venipuncture between $0900 \mathrm{~h}$ and $1000 \mathrm{~h}$ to minimize variability due to circadian cortisol rhythms, divided for wholeblood use and for PBMC isolation, and processed immediately. PBMC were isolated using a Ficoll-Paque gradient (Amersham Biosciences, Uppsala, Sweden), washed twice with RPMI 1640, and resuspended for use according to the protocols of the various GC sensitivity assays.

\section{Inhibition of mitogen-stimulated proliferation of PBMC by DXM}

We have performed four mitogen-based GC sensitivity assays on the blood samples, which have all been described in detail in recent literature. Two of them are based on the use of diluted wholeblood, wb-I (16) and wb-II (15), and two are based on isolated PBMC, PBMC-I (11) and PBMC-II (13). The differences between the GC sensitivity assays are summarized in Table 1. All mitogen-based assays were performed in 96-well round bottom plates, incubated in a humidified atmosphere with $5 \% \mathrm{CO}_{2}$ at $37^{\circ} \mathrm{C}$, and inhibition of proliferation was determined using DXM (SigmaAldrich Chemie, Steinheim, Germany) in concentrations as indicated.

Briefly, the wb-I assay used wholeblood, diluted 1:10 with RPMI 1640 medium (Invitrogen Corp., Paisley, Strathclyde, UK) with 10\% fetal calf serum (FCS) (Invitrogen Corp.), divided into $150 \mu$ l aliquots. Phytohaemagglutinnin (PHA) $(5 \mu \mathrm{g} / \mathrm{ml}$ final concentration; SigmaAldrich Chemie) and DXM were added to an endvolume of $200 \mu \mathrm{l}$, and the last $6 \mathrm{~h}$ of the $48-\mathrm{h}$ incubation was in the presence of $0.5 \mu \mathrm{Ci}^{3} \mathrm{H}$-thymidine/well. The wb-II assay used wholeblood, diluted 1:10 with RPMI 1640 medium and divided into $100 \mu \mathrm{l}$ aliquots. PHA $(25 \mu \mathrm{g} / \mathrm{ml}$ final concentration; Murex Diagnostics, Dartford, Kent, UK) and DXM were added to an endvolume of $150 \mu$ l. The cells were incubated for $96 \mathrm{~h}$, the last $16-18 \mathrm{~h}$ in the presence of $1 \mu \mathrm{Ci}^{3} \mathrm{H}$-thymidine/well. The PBMC-I assay used isolated PBMC in RPMI 1640 medium supplemented with $10 \%$ FCS, each well containing $4 \times 10^{5}$ cells in $150 \mu \mathrm{l}$. PHA $(5 \mu \mathrm{g} / \mathrm{ml}$ final concentration) and DXM were added to an endvolume of $200 \mu \mathrm{l}$, and the last $6 \mathrm{~h}$ of the 48-h incubation was in the presence of $0.5 \mu \mathrm{Ci}^{3} \mathrm{H}$-thymidine/well. The PBMC-II assay was performed using isolated PBMC in RPMI 1640 supplemented with $10 \%$ dextran-coated charcoal (DCC)stripped FCS, each well containing $4 \times 10^{5}$ cells in $150 \mu \mathrm{l}$. PHA ( $5 \mu \mathrm{g} / \mathrm{ml}$ final concentration) and DXM were added to an endvolume of $200 \mu \mathrm{l}$. PBMC were incubated for $96 \mathrm{~h}$, the last $4 \mathrm{~h}$ in the presence of $0.5 \mu \mathrm{Ci}^{3} \mathrm{H}$-thymidine/well.

Table 1 Characteristics of the cellular GC sensitivity assays. The amount of mononuclear cells in both wholeblood-based assays (wb-I, wb-II) is an approximation based on mean normal values.

\begin{tabular}{|c|c|c|c|c|c|c|}
\hline Assay & PBMC/well & PHA & $\begin{array}{c}\text { Total GC/PHA } \\
\text { incubation time }\end{array}$ & ${ }^{3} \mathrm{H}$ incorporation & FCS & Reference \\
\hline$w b-I$ & $\begin{array}{c}150 \mu \text { l diluted } \\
\text { wholeblood } \\
\left(1.5 \times 10^{4} \text { cells }\right)\end{array}$ & $5 \mu \mathrm{g} / \mathrm{ml}$ (Sigma) & $48 \mathrm{~h}$ & Last $6 \mathrm{~h}(0.5 \mu \mathrm{Ci})$ & $10 \%$ & 16 \\
\hline wb-II & $\begin{array}{c}100 \mu \text { l diluted } \\
\text { wholeblood } \\
\left(1 \times 10^{4} \text { cells }\right)\end{array}$ & $25 \mu \mathrm{g} / \mathrm{ml}$ (Murex) & $96 \mathrm{~h}$ & Last $16-18 \mathrm{~h}(1.0 \mu \mathrm{Ci})$ & - & 15 \\
\hline PBMC-I & PBMC $\left(4 \times 10^{5}\right.$ cells $)$ & $5 \mu \mathrm{g} / \mathrm{ml}$ (Sigma) & $48 \mathrm{~h}$ & Last $6 \mathrm{~h}(0.5 \mu \mathrm{Ci})$ & $10 \%$ & 11 \\
\hline PBMC-II & PBMC $\left(4 \times 10^{5}\right.$ cells $)$ & $5 \mu \mathrm{g} / \mathrm{ml}$ (Sigma) & $96 \mathrm{~h}$ & Last $4 \mathrm{~h}(0.5 \mu \mathrm{Ci})$ & $10 \%$ DCC-stripped & 13 \\
\hline FKBP51 & PBMC $\left(4 \times 10^{5}\right.$ cells $)$ & - & $24 \mathrm{~h}$ & - & 10\% DCC-stripped & 22 \\
\hline
\end{tabular}


After incubation, cells were harvested using an automated cell harvester and incorporated radioactivity was determined in a liquid scintillation counter (Wallac, Turku, Finland).

\section{FKBP51 bioassay}

Isolated PBMC were resuspended to a concentration of $4.4 \times 10^{5} \mathrm{cells} / \mathrm{ml}$ in RPMI 1640 medium, supplemented with 10\% DCC-stripped FCS, 4 mM L-glutamine, $100 \mathrm{IU} / \mathrm{ml}$ penicillin, and $100 \mu \mathrm{g} / \mathrm{ml}$ streptomycin. PBMC were divided into $0.9 \mathrm{ml}$ aliquots onto a 48 -well plate. Following an overnight preincubation to minimize the effects of endogenous glucocorticoids, DXM was added to an endvolume of $1 \mathrm{ml} /$ well, followed by a $24-\mathrm{h}$ incubation after which total RNA was isolated using TriPure reagent (Roche Applied Science, Mannheim, Germany), and reverse transcribed using MMLV-RT RNase H Minus, Point Mutant (Promega, Madison, WI, USA), according to the manufacturer's protocols. Relative FKBP51 transcription levels were determined as described previously (22), by real-time PCR using the LightCycler (Roche Applied Science).

Briefly, the relative expression level of the housekeeping gene $\beta 2$-microglobulin $\left(\beta_{2} \mathrm{~m}\right)$ was determined in each sample, and this was used to calculate the relative expression level of FKBP51. The PCR reactions $(10 \mu \mathrm{l}$ endvolume) were performed using the DNA Master SYBR-green I kit (Roche Applied Science, Mannheim, Germany), and contained 5.0 $\mu \mathrm{l}$ 1:40 diluted cDNA, $0.5 \mathrm{pmol} / \mu \mathrm{l}$ of each primer, $10 \%$ DNA master SYBRgreen I solution, and $\mathrm{MgCl}_{2}\left(\beta_{2} \mathrm{~m}, 4 \mathrm{mM}\right.$; FKBP51, $3 \mathrm{mM})$. The mixture was denatured $\left(30 \mathrm{~s}\right.$ at $\left.95^{\circ} \mathrm{C}\right)$ and subjected to up to 40 amplification cycles: denaturing $15 \mathrm{~s}$ at $95^{\circ} \mathrm{C}$, annealing $10 \mathrm{~s}\left(\beta_{2} \mathrm{~m}, 56^{\circ} \mathrm{C}\right.$; FKBP 51 , $67^{\circ} \mathrm{C}$ ), and elongation for $30 \mathrm{~s}$ at $72^{\circ} \mathrm{C}$, followed by a single measurement of fluorescence at $82^{\circ} \mathrm{C}$.

\section{Statistics}

Experiments were performed in quadruplicate. The sigmoid dose-response curves of the mitogen-based assays were analyzed by non-linear regression using Graphpad Prism software version 3.0 (Graphpad Software Inc., San Diego, CA, USA), to obtain the parameters $\mathrm{E}_{\max }$ and $\mathrm{EC}_{50}$. The difference between untreated and PHA-treated PBMC was calculated using a paired $t$-test. Statistical analyses were performed using Graphpad Instat software version 3.00 (Graphpad Software Inc.).

\section{Results}

The intra-assay $\mathrm{CV}$ of $\mathrm{E}_{\max }$ and $\mathrm{EC}_{50}$ were compared between the mitogen-based GC sensitivity assays. The relative increase of FKBP51 mRNA following incubations with $10^{-9}$ and $10^{-6} \mathrm{MDXM}$ (on average the lowest DXM concentration to induce FKBP51 mRNA, and the highest DXM concentration tested respectively) have been used as parameters to assess the variation of the FKBP51 assay. Ten controls were assayed in quadruplicate, and the average $\mathrm{CV}$ showed a large intraassay variation for both $\mathrm{E}_{\max }$ and $\mathrm{EC}_{50}$ compared with the variation in the FKBP51 assay (Table 2).

Next, we assessed the cellular GC sensitivities of ten controls and a partially GC-resistant patient using the five assays (Fig. 1). The higher suppression of proliferation in the wholeblood-based mitogen assays suggested a slightly increased GC sensitivity in controls, as compared with the PBMC-based mitogen assays. Both wholeblood-based mitogen assays and the FKBP51 assay demonstrated GC resistance in the patient's PBMC. Surprisingly, however, both PBMC-based mitogen assays suggested an increased GC sensitivity of the patient's PBMC at low DXM concentrations, although higher DXM concentrations in the PBMC-II assay revealed the patient's GC resistance.

In addition, we compared the calculated parameters $\mathrm{EC}_{50}$ and $\mathrm{E}_{\max }$ of the wholeblood-based, and the PBMC-based mitogen assays. Figure 2A shows the $\mathrm{EC}_{50}$ of the wb-I and wb-II assay, and Fig. 2B compares their $\mathrm{E}_{\max }$ to the relative increase of FKBP51 mRNA following incubation with $10^{-6} \mathrm{M}$ DXM. Figure 2C shows the $\mathrm{EC}_{50}$ of the PBMC-I and PBMC-II assays, and Fig. 2D compares their $\mathrm{E}_{\max }$ with FKBP51 mRNA levels. Relative GC sensitivity, when determined using the $\mathrm{EC}_{50}$ parameter, remained fairly constant within the subjects tested between the different mitogen assays. In contrast to expectations, however, the $\mathrm{EC}_{50}$ of the GC-resistant patient as determined in both PBMCbased mitogen assays was suggestive of GC hypersensitivity. The $\mathrm{E}_{\text {max }}$ parameter showed more within-subject variation between the different mitogen assays as compared with the $\mathrm{EC}_{50}$ parameter. Nevertheless, the $\mathrm{E}_{\max }$ parameter in both wholeblood-based mitogen assays and the PBMC-II assay confirmed the GC resistance of the patient's blood cells, whereas in the PBMC-I assay the $\mathrm{E}_{\max }$ was unable to distinguish this GC-resistant patient from controls. The relative increase of FKBP51 mRNA compared with controls was diminished in the patient's PBMC.

To assess whether, and to what extent, the results of these assays vary over time within the same subjects, we repeated the assays with six controls 4 weeks later (Table 3). The intra-individual CV was

Table 2 Average intra-assay $C V$ for $E_{\max }, E_{50}$, and the relative increase of FKBP51 mRNA after incubation with $10^{-9}$ or $10^{-6} \mathrm{M}$ DXM.

\begin{tabular}{lcccccc}
\hline & $\begin{array}{c}\text { wb-I } \\
(\%)\end{array}$ & $\begin{array}{c}\text { wb-II } \\
(\%)\end{array}$ & $\begin{array}{c}\text { PBMC-I } \\
(\%)\end{array}$ & $\begin{array}{c}\text { PBMC-II } \\
(\%)\end{array}$ & $\begin{array}{c}\text { FKBP51 } \\
(\%)\end{array}$ \\
\hline $\mathrm{E}_{\max }$ & 40.4 & 50.6 & 42.5 & 36.6 & $10^{-9} \mathrm{M}$ DXM & 22.7 \\
EC $_{50}$ & 54.1 & 33.5 & 51.8 & 39.1 & $10^{-6} \mathrm{M}$ DXM & 16.7 \\
\hline
\end{tabular}



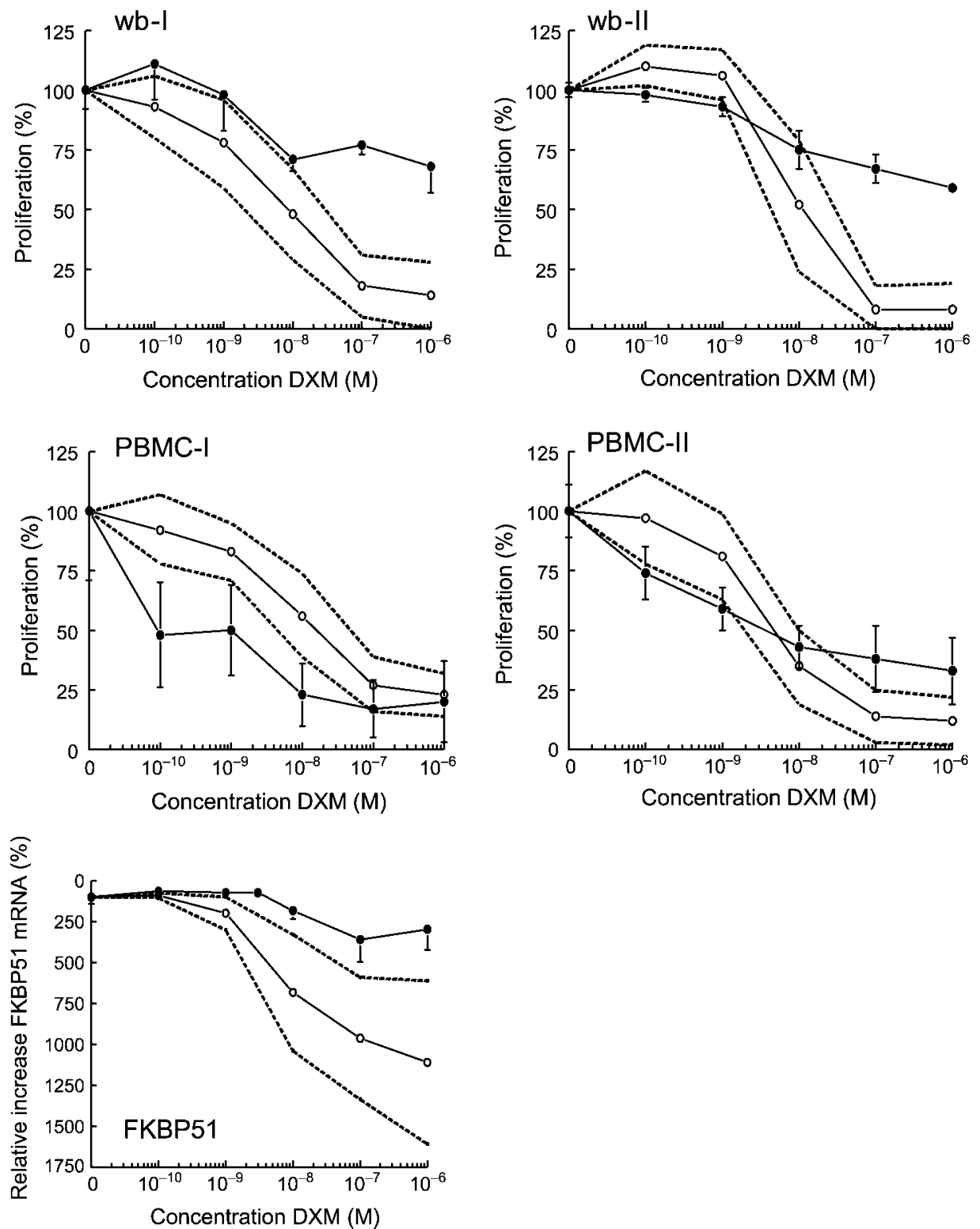

Figure 1 The cellular GC sensitivity of controls and a GC-resistant patient was assessed in five in vitro assays. The mean \pm S.D. of controls (o); $n=10$; dotted lines represent \pm S.D.) and patient ( $\bullet$ ) of determinations in quadruplicate are shown. Mitogen-stimulated PBMC without administered DXM were set at 100\%. Note the inversion of the ordinate in the graph displaying the FKBP51 assay results.

calculated for the parameters $\mathrm{E}_{\max }$ and $\mathrm{EC}_{50}$, and for the relative mRNA levels at $10^{-9} \mathrm{M}$ and $10^{-6} \mathrm{M}$ DXM. $E_{\max }$ showed, on average, less intra-individual variation compared with $\mathrm{EC}_{50}$, whereas the intraindividual variation of the FKBP51 mRNA increase was lower than either the $\mathrm{E}_{\max }$ or the $\mathrm{EC}_{50}$ of the mitogen assays.

To establish the effect of mitogen stimulation on lymphocyte GC sensitivity as determined with the FKBP51 assay, we incubated PBMC of three healthy subjects with or without $5 \mu \mathrm{g} / \mathrm{ml}$ PHA for $96 \mathrm{~h}$. DXM was added for the last $24 \mathrm{~h}$ of the incubation. As shown in Fig. 3, unstimulated PBMC responded clearly to GC administration with a more than tenfold increase in FKBP51 mRNA, whereas PHA-stimulated PBMC showed a strongly diminished increase by a factor of 2 at best.

\section{Discussion}

A potentially important disadvantage of the use of mitogen-stimulated lymphocytes to determine cellular GC sensitivity in general is the profound alteration of lymphocytic gene and protein expression. Effects have been reported, among others, on cytokine expression, 

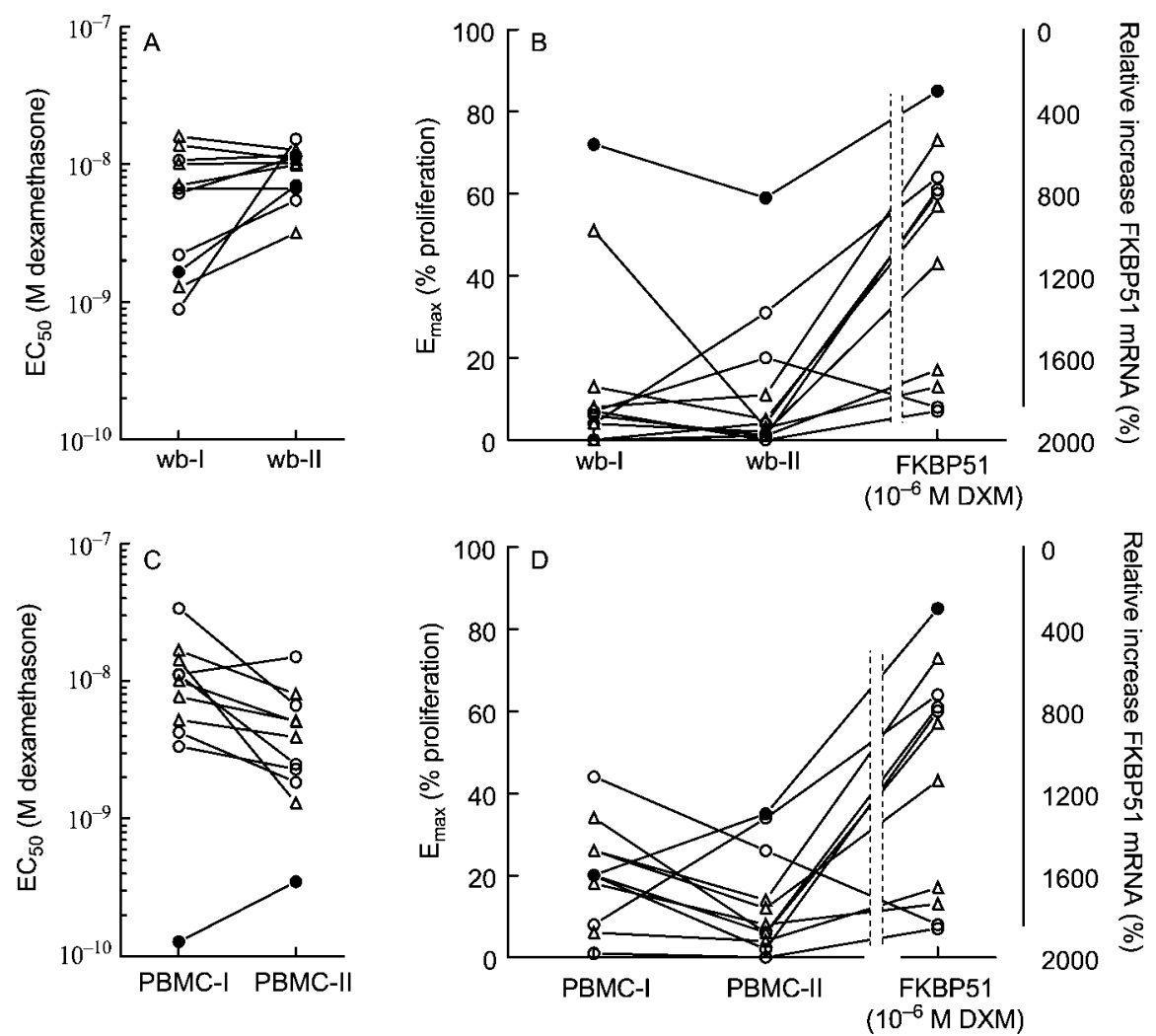

Figure 2 The GC sensitivity of ten controls and a GC-resistant patient was assessed, and compared using the parameters $\mathrm{EC}_{50}$ and $E_{\max }$ for the mitogen assays, and the relative increase of FKBP51 mRNA at $10^{-6} \mathrm{M}$ DXM for the FKBP51 assay. (A) Comparison of $E_{50}$ in wholeblood-based mitogen assays. (B) Comparison of $E_{\max }$ in wholeblood-based mitogen assays (left $Y$-axis), and relative FKBP51 mRNA expression in the FKBP51 assay (right Y-axis, note the inversion). (C) Comparison of $\mathrm{EC}_{50}$ in PBMC-based mitogen assays. (D) Comparison of $E_{\max }$ in PBMC-based mitogen assays (left $Y$-axis), and relative FKBP51 mRNA expression in the FKBP51 assay (identical to (B); right $\mathrm{Y}$-axis, note the inversion). The average of quadruplicate determinations are shown. (Female $(\circ)$; male $(\triangle)$; GC-resistant patient (•)).

topoisomerase I regulation, and nuclear transcription factors $(18,19,24)$. These alterations can lead to changes in lymphocytic GC sensitivity. Therefore, when studying the GC responsiveness of cells in general, one might better choose a more 'direct' read-out frame, one that is as close as possible to the GC receptor (GR) - glucocorticoid response element (GRE) interaction and the subsequent GR-associated transcription machinery. The mRNA expression level of genes that are directly up- or downregulated by GC are ideally suited for this purpose. Among them is the mRNA encoding the immunophilin FKBP 51, which is strongly upregulated by GC.

The diminished responsiveness to DXM of PHAstimulated PBMC in the FKBP51 assay, as described in

Table 3 Average intra-individual $\mathrm{CV}$ for $\mathrm{E}_{\max }, \mathrm{EC}_{50}$, and the relative increase of FKBP51 mRNA after incubation with $10^{-9}$ or $10^{-6}$ M DXM.

\begin{tabular}{lcccccc}
\hline $\begin{array}{c}\text { wb-I } \\
(\%)\end{array}$ & $\begin{array}{c}\text { wb-II } \\
(\%)\end{array}$ & $\begin{array}{c}\text { PBMC-I } \\
(\%)\end{array}$ & $\begin{array}{c}\text { PBMC-II } \\
(\%)\end{array}$ & $\begin{array}{c}\text { FKBP51 } \\
(\%)\end{array}$ \\
\hline $\mathrm{E}_{\max }$ & 51.5 & 49.7 & 68.4 & 50.3 & $10^{-9} \mathrm{M}$ DXM & 28.6 \\
$\mathrm{EC}_{50}$ & 67.4 & 62.8 & 48.7 & 77.5 & $10^{-6} \mathrm{M}$ DXM & 17.6 \\
\hline
\end{tabular}

this study, confirms that the mitogen-based assays and the FKBP51 assay represent different aspects of GC-induced changes in cellular - i.e. lymphocytic sensitivity. Thus, the use of PHA-stimulated PBMC

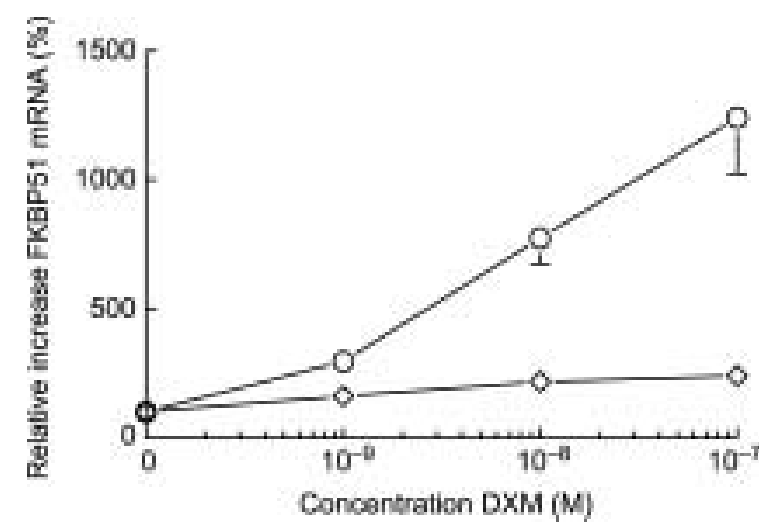

Figure 3 Native PBMC were cultured for $96 \mathrm{~h}$ with $5 \mu \mathrm{g} / \mathrm{ml} \mathrm{PHA}$ $(\diamond)$, and without PHA $(O)$. During the last $24 \mathrm{~h}$ of the incubation DXM in the concentrations indicated was added, and relative FKBP51 mRNA levels were determined. 
in GC sensitivity assays may be warranted to assess the sensitivity to GC-induced immunosuppression, which appears to be mediated mainly by interactions of the activated GR with nuclear proteins, such as activator protein-1 and nuclear factor- $\mathrm{B}(25,26)$, although it could be argued that, even then, PBMC stimulation using a specific antigen such as tetanus toxoid might more closely resemble a physiological immune response. In contrast, the FKBP51 assay may be superior in detecting general changes in cellular GC sensitivity, e.g. based on changes in receptor number, or affinity, or alterations in the basal transcription machinery.

The GC resistance in the patient we studied is caused by a diminished GC receptor expression with unaltered ligand affinity $(14,23)$. In GC sensitivity assays this should be reflected in a diminished $\mathrm{E}_{\max }$, with $\mathrm{EC}_{50}$ values equivalent to those of the control subjects (14). The wholeblood-based mitogen assays as well as the FKBP51 assay indeed showed the expected response. However, the isolated PBMCbased mitogen assays reacted quite differently: in the PBMC-I assay, $E_{\max }$ was entirely comparable with normal, while $\mathrm{E}_{\max }$ in the PBMC-II assay reflected the patient's GC resistance relatively poorly. Moreover, both PBMC-based mitogen assays showed a lowered $\mathrm{EC}_{50}$ in the patient's lymphocytes as compared with control subjects, which would seem to indicate an increased rather than a decreased sensitivity to GCs of the patient's PBMC. An explanation for these conflicting findings may be that the patient was on long-standing GC medication $(0.5 \mathrm{mg}$ $\mathrm{DXM} /$ day). This may have changed the protein expression pattern of the PBMC and the serum concentration of ancillary factors required for the response of the PBMC to an immunogenic challenge. Isolated PBMC may thus become less capable of responding to the administered mitogens. Indeed, we observed a reduction of the proliferative response of the patient's PBMC to PHA stimulation in both PBMC-based mitogen assays (PBMC-I, 9204 c.p.m.; PBMC-II, 1342 c.p.m.) compared with controls (range PBMC-I, 9098-40 455 c.p.m.; range PBMC-II, 2676-18042 c.p.m.), whereas neither of the wholeblood-based mitogen assays exhibited such a reduced proliferation compared with controls.

The FKPB51 assay is less likely to be influenced by factors affecting proliferation, since it obviates the need for immunogenic stimulation. Moreover, following the preincubation step, the FKBP51 mRNA expression of the patient's lymphocytes was comparable with expression in control PBMC, suggesting that the prolonged GC medication had not affected the constitutive FKBP51 mRNA expression. Thus, especially for patients or patient groups whose GC sensitivity needs to be assessed while on treatment with GC, the FKBP51 assay may be superior to proliferation-inhibition assays, since it uses isolated PBMC without the need for prior stimulation, while ascertaining a basal level in the response of the isolated PBMC by an overnight 'resetting' step in steroid-stripped medium.

Reports on inter- and intra-assay variations of the mitogen-based assays are scant. We found a rather high intra-assay variation both for $\mathrm{EC}_{50}$ and $\mathrm{E}_{\max }$ in all of them. A lower intra-assay variation for $\mathrm{E}_{\max }$ has previously been reported in the PBMC-I assay, based on only one control (11), whereas we have determined the average intra-assay variation of ten controls, which may have caused this discrepancy. To the best of our knowledge, intra-assay or intra-individual variations for $\mathrm{E}_{\max }$ and $\mathrm{EC}_{50}$ have not been reported before for the other mitogen-based assays we have performed. The intra-individual variation of the increase in FKBP51 mRNA at $10^{-9} \mathrm{M}$ and especially $10^{-6} \mathrm{MDXM}$, was smaller than either that of $\mathrm{E}_{\max }$ or $\mathrm{EC}_{50}$ of the mitogen assays, indicating that GC-induced FKBP51 mRNA increase may be more reproducible within individuals than GCinduced inhibition of proliferation. It has been reported recently that the $\mathrm{E}_{\max }$ of isolated $\mathrm{PBMC}$ in mitogenbased assays ranges from $0 \%$ to almost $100 \%(11,16)$. Like others $(14,17,27,28)$, we could not detect such a wide variation with any of the mitogen-based assays we have performed, as the $\mathrm{E}_{\max }$ ranged from $51.8 \%$ to $96.6 \%$. Although we have performed the assays exactly as described in the literature, slight differences in experimental procedures and the number of control subjects tested may have caused this discrepancy. The higher sensitivity of mitogen-stimulated PBMC to GCs in the wholeblood-based mitogen assays as found by us is in concordance with previous observations (16). As a consequence, the $\mathrm{E}_{\max }$ shows less variation between subjects, thus wholeblood-based assays may be less able to distinguish between different levels of GC sensitivity.

In conclusion, in investigating the origin and consequences of altered GC sensitivity, the mitogen-based assays and the FKBP51 assay appear to complement each other. Alterations in the capacity of the GR to engage in nuclear protein-protein interactions may be more pronounced using PBMC proliferation assays, whereas alterations in GR/DNA-binding and the GR-associated transcription machinery may be reflected better by the FKBP51 assay. Although the results obtained with the FKBP51 assay have yet to be correlated with clinical outcome when GCs are used for immunosuppression, it is already clear that the FKBP51 assay has its advantages: it shows smaller assay variations, is less likely to be influenced by serum-related variables, does not require mitogen-activated PBMC, and may therefore overall be better suited to assess in vivo cellular GC sensitivity.

\section{Acknowledgements}

The authors would like to thank Dr A Kavelaars for critically reading the manuscript. This study was 
supported by a research grant from Ferring B.V., The Netherlands.

\section{References}

1 Grebe SK, Feek CM, Durham JA, Kljakovic M \& Cooke RR. Inhaled beclomethasone dipropionate suppresses the hypothalamo-pituitary-adrenal axis in a dose dependent manner. Clinical Endocrinology 199747 297-304.

2 Nishimura J \& Ikuyama S. Glucocorticoid-induced osteoporosis: pathogenesis and management. Journal of Bone and Mineral Metabolism 200018 350-352.

3 Slater JHD, Heffron PF, Vernet A \& Nabarro JDN. Clinical and metabolic effects of dexamethasone. Lancet $19591173-177$.

4 Harrison TW, Wisniewski A, Honour J \& Tattersfield AE. Comparison of the systemic effects of fluticasone propionate and budesonide given by dry powder inhaler in healthy and asthmatic subjects. Thorax 200156 186-191.

5 Umland SP, Schleimer RP \& Johnston SL. Review of the molecular and cellular mechanisms of action of glucocorticoids for use in asthma. Pulmonary Pharmacology and Therapeutics 200215 35-50.

6 Zimmerman B, Gold M, Wherrett D \& Hanna AK. Adrenal suppression in two patients with asthma treated with low doses of the inhaled steroid fluticasone propionate. Journal of Allergy and Clinical Immunology $1998 \mathbf{1 0 1} 425-426$.

7 Lamberts SW, Huizenga NA, de Lange P, de Jong FH \& Koper JW. Clinical aspects of glucocorticoid sensitivity. Steroids $1996 \mathbf{6 1}$ 157-160.

8 Kino T \& Chrousos GP. Glucocorticoid and mineralocorticoid resistance/hypersensitivity syndromes. Journal of Endocrinology 2001 $169437-445$.

9 Raivio T, Palvimo JJ, Kannisto S, Voutilainen R \& Jänne OA. Transactivation assay for determination of glucocorticoid bioactivity in human serum. Journal of Clinical Endocrinology and Metabolism 200287 3740-3744.

10 Vermeer H, Hendriks-Stegeman BI, Van den Brink CE, Van der Saag PT, Van der Burg B, Van Buul-Offers SC et al. A novel specific bioassay for the determination of glucocorticoid bioavailability in human serum. Clinical Endocrinology 200359 49-55.

11 Hearing SD, Norman M, Smyth C, Foy C \& Dayan CM. Wide variation in lymphocyte steroid sensitivity among healthy human volunteers. Journal of Clinical Endocrinology and Metabolism 199984 4149-4154.

12 Spahn JD, Landwehr LP, Nimmagadda S, Surs W, Leung DY \& Szefler SJ. Effects of glucocorticoids on lymphocyte activation in patients with steroid-sensitive and steroid-resistant asthma. Journal of Allergy and Clinical Immunology $1996 \mathbf{9 8}$ 1073-1079.

13 Huizenga NA, de Lange P, Koper JW, De Herder WW, Abs R, Kasteren JHLMV et al. Five patients with biochemical and/or clinical generalized glucocorticoid resistance without alterations in the glucocorticoid receptor gene. Journal of Clinical Endocrinology and Metabolism 2000 85 2076-2081.

14 Lamberts SW, Koper JW, Biemond P, Den Holder FH \& de Jong FH. Cortisol receptor resistance: the variability of its clinical presentation and response to treatment. Journal of Clinical Endocrinology and Metabolism $1992 \mathbf{7 4} 313-321$.
15 Kavelaars A, Kuis W, Knook L, Sinnema G \& Heijnen CJ. Disturbed neuroendocrine-immune interactions in chronic fatigue syndrome. Journal of Clinical Endocrinology and Metabolism $2000 \mathbf{8 5}$ 692-696.

16 Hearing SD, Norman M \& Dayan CM. In vitro measurement of lymphocyte steroid sensitivity: lack of agreement between whole blood culture and separated lymphocyte culture. Immunopharmacology and Immunotoxicology 199921 41-53.

17 Van Reijen EAM, Harvey RA, Barton RN, Rose JG \& Horan MA. Sensitivity of mononuclear leucocytes to glucocorticoids in elderly hip-fracture patients resistant to suppression of plasma cortisol by dexamethasone. European Journal of Endocrinology $1998 \mathbf{1 3 8}$ 659-666.

18 Fan J, Nishanain P, Breen EC, McDonald M \& Fahey JL. Cytokine gene expression in normal human lymphocytes in response to stimulation. Clinical and Diagnostic Laboratory Immunology 1998 $5335-340$.

19 Chen H-J, Hwong C-L, Wang C-H \& Hwan J. Degradation of DNA topoisomerase I by a novel trypsin-like serine protease in proliferating human T lymphocytes. Journal of Biological Chemistry 2000 275 13109-13117.

20 Reguzzoni M, Cosentino M, Rasini E, Marino F, Ferrari M, Bombelli $\mathrm{R}$ et al. Ultrastructural localization of tyrosine hydroxylase in human peripheral blood mononuclear cells: effect of stimulation with phytohaemagglutinin. Cell and Tissue Research 2002310 297-304.

21 Baughman G, Wiederrecht GJ, Campbell NF, Martin MM \& Bourgeois S. FKBP51, a novel T-cell-specific immunophilin capable of calcineurin inhibition. Molecular and Cellular Biology $1995154395-4402$.

22 Vermeer H, Hendriks-Stegeman BI, Van der Burg B, Van Buul-Offers SC \& Jansen M. Glucocorticoid-induced increase in lymphocytic FKBP51 mRNA expression: a potential marker for glucocorticoid sensitivity, potency and bioavailability. Journal of Clinical Endocrinology and Metabolism 200388 277-284.

23 Karl M, Lamberts SW, Detera-Wadleigh SD, Encio IJ, Stratakis CA, Hurley DM et al. Familial glucocorticoid resistance caused by a splice site deletion in the human glucocorticoid receptor gene. Journal of Clinical Endocrinology and Metabolism $1993 \mathbf{7 6}$ 683-689.

24 Tay DL, Hoffbrand AV \& Wickremasinghe GR. Expression of c-fos and $c$-jun proteins and AP-1 binding activity during cell cycle progression of HL60 cells and phytohemagglutinin-stimulated lymphocytes. Experimental Hematology $1996 \mathbf{2 4} 277-284$.

25 Herrlich P. Cross-talk between glucocorticoid receptor and AP-1. Oncogene 200120 2465-2475.

26 Jonat C, Rahmsdorf HJ, Park K-K, Cato ACB, Gebel S, Ponta H et al. Novel glucocorticoid receptor coactivator effector mechanisms. Cell 199062 1189-1204.

27 Kraft M, Vianna E, Martin RJ \& Leung DM. Nocturnal asthma is associated with reduced glucocorticoid receptor binding affinity and decreased steroid responsiveness at night. Journal of Allergy and Clinical Immunology 1999103 66-71.

28 Wei T, Knight RA \& Lightman S. Mitogenic response and steroid sensitivity in MS lymphocytes. Acta Neurologica Scandinavia 1997 $9628-33$.

Received 16 July 2003

Accepted 8 October 2003 